\title{
Peningkatan Kemampuan Interaksi Pada Pasien Isolasi Sosial Dengan Penerapan Terapi Aktivitas Kelompok Sosialisasi Sesi 1-3
}

\author{
Suwarni' ${ }^{1}$ Desi Ariyana Rahayu ${ }^{2}$ \\ 1,2 Program Studi Pendidikan Profesi Ners, Fakultas Ilmu Keperawatan dan Kesehatan, Universitas \\ Muhammadiyah Semarang
}

\section{Informasi Artikel}

\section{Riwayat Artikel:}

- Submit 27 Februari 2020

- Diterima 4 Mei 2020

\section{Kata kunci:}

Terapi Aktivitas Kelompok Sosialisasi, Kemampuan Interaksi Komunikasi, Isolasi Sosial

\begin{abstract}
Abstrak
Penderita yang mengalami gangguan jiwa di RSJD Amino Gondohutomo Provinsi Jawa Tengah pada tahun 2018-2019 adalah sebanyak 2557 orang yang diantaranya terdapat penderita isolasi sosial 560 orang $(21,9 \%)$. Kondisi diatas menggambarkan prevalensi masalah kesehatan jiwa baik gangguan jiwa ringan sampai berat cukup tinggi dan membutuhkan penanganan yang serius serta berkesinambungan. Isolasi sosial adalah keadaan dimana seorang individu mengalami penurunan atau bahkan sama sekali tidak mampu berinteraksi dengan orang lain di sekitarnya. Terapi Aktivitas Kelompok sangat efektif mengubah perilaku karena di dalam kelompok terjadi interaksi satu dengan yang lain dan saling mempengaruhi. Penerapan TAKS sesi 1-3 dilakukan selama 3 hari, evaluasi penerapan dilakukan setiap per sesi dan post-test dilakukan dihari keempat penerapan. Sampel pada penerapan ini berjumlah 2 responden yang dipilih menggunakan tekhnik random sampling yaitu pemilihan responden secara acak. Hasil penelitian menunjukkan terdapat pengaruh TAKS sesi 1-3 terhadap peningkatan kemampuan interaksi pada pasien menarik diri di RSJD Dr. Amino Gondohutomo Provinsi Jawa Tengah. TAKS sesi 1-3 dapat meningkatkan kemampuan interaksi pada pasien menarik diri di RSJD Dr. Amino Gondohutomo Provinsi Jawa Tengah.
\end{abstract}

\section{PENDAHULUAN}

Berdasarkan Riset Kesehatan Dasar (Riskesdas) Pada tahun 2018 di Indonesia prevalensi gangguan jiwa mencapai $7 \%$ dari 1000 orang sedangkan prevalensi untuk gangguan jiwa diatas usia 15 tahun yang berkisar rata-rata 9,8\% (Rachmaningtyas, 2013). Prevalensi skizofrenia yang ada di Indonesia rata-rata 1-2 \% dari jumlah penduduk dan usia paling banyak penderita skizofrenia di alami sekitar 15-35 tahun (Makhfudi, 2010). Hasil penelitian WHO di Jawa Tengah tahun 2009 menyebutkan dari setiap 1.000 warga Jawa Tengah terdapat 3 orang yang mengalami ganguan jiwa. Sementara 19 orang dari setiap 1.000 warga Jawa Tengah mengalami stress (DEPKES RI, 2016). Berdasarkan hasil pencatatan jumlah penderita yang mengalami gangguan jiwa di RSJD Amino Gondohutomo Provinsi Jawa Tengah pada tahun 2018-2019 adalah sebanyak 2557 orang yang diantaranya terdapat penderita isolasi sosial 560 orang $(21,9 \%)$. Kondisi diatas menggambarkan prevalensi masalah kesehatan jiwa baik gangguan jiwa ringan sampai berat cukup tinggi dan membutuhkan penanganan yang serius serta berkesinambungan.

Kemunduran fungsi sosial yang dialami seseorang di dalam diagnosa keperawatan jiwa disebut isolasi sosial. Perilaku menarik diri merupakan percobaan untuk menghindari interaksi dengan orang lain, menghindari hubungan maupun komunikasi dengan orang lain. Isolasi sosial

Corresponding author:

Suwarni

Arny1407070@gmail.com

Ners Muda, Vol 1 No 1, April 2020

e-ISSN:

DOI: $10.26714 / \mathrm{nm} . v 1 \mathrm{i} 1.5482$ 
adalah keadaan dimana seorang individu mengalami penurunan atau bahkan sama sekali tidak mampu berinteraksi dengan orang lain di sekitarnya. Pasien mungkin merasa ditolak, tidak diterima, kesepian, dan tidak mampu membina hubungan yang berarti dengan orang lain (Yosep, 2011). Perilaku yang sering ditampilkan Pasien isolasi sosial adalah menunjukkan menarik diri, tidak komunikatif, mencoba menyendiri, asyik dengan pikiran dan dirinya sendiri, tidak ada kontak mats, sedih, afek tumpul, perilaku bermusuhan, menyatakan perasaan sepi atau ditolak kesulitan membina hubungan di lingkungannya, menghindari orang lain, dan mengungkapkan perasaan tidak dimengerti orang lain (Keliat, 2014).

Penatalaksanaan keperawatan Pasien dengan isolasi sosial selain dengan pengobatan psikofarmaka juga dengan pemberian terapi modalitas yang salah keperawatan yang sama. Aktifitas digunakan sebagai terapi, dan kelompok digunakan sebagai target asuhan (Yosep, 2011).

Terapi Aktivitas Kelompok sangat efektif mengubah perilaku karena di dalam kelompok terjadi interaksi satu dengan yang lain dan saling mempengaruhi. Dalam kelompok akan terbentuk satu sistem sosial yang saling berinteraksi dan menjadi tempat Pasien berlatih perilaku baru yang adaptif untuk memperbaiki perilaku lama yang maladaptif. TAKS adalah upaya memfasilitasi sosialisasi sejumlah pasien dengan perilaku menarik diri secara kelompok (Keliat, 2014). TAKS terdiri atas 7 sesi, dalam penerapan ini TAKS yang dilakukan TAKS sesi 1-3 karena sesuai dengan tujuan dari TAKS sesi 1-3 itu sendiri, yaitu : (1) pasien mampu memperkenalkan diri yang meliputi nama lengkap, nama panggilan, asal dan hobi. (2) pasien mampu berkenalan dengan anggota kelompok. (3) pasien mampu bercakap-cakap dengan anggota kelompok tentang topik yang disenangi. (4) Mengetahui peningkatan kemampuan pasien setelah mengikuti kegiatan TAKS sesi 1-3 di Ruang RIPD RSJD Amino Gondohutomo Provinsi Jawa Tengah. Sehingga setelah pasien melakukan TAKS sesi 1-3 kemampuan komunikasi pasien akan meningkat dan hal ini akan meningkatkan kemampuan interaks (Keliat, B.A 2013).

Beberapa penelitian mengenai pengaruh Terapi Aktivitas Kelompok terhadap Pasien dengan masalah keperawatan isolasi sosial seperti penelitian yang dilakukan oleh (Julianto A. B, Dwi H. R, 2015) di rumah sakit jiwa Dr. Radjiman Wedioningrat Lawang, menunjukkan persentasi pelaksanaan yang memuaskan yaitu mencapai tingkat keberhasilan $90 \%$ dimana mampu meningkatkan kemampuan pasien untuk berinteraksi sosial. (Pribadi et al., 2016) menunjukkan adanya pengaruh yang bermakna dari pelaksanaan Terapi Aktivitas Kelompok Sosialisasi. Keberhasilan ini dipengaruhi oleh beberapa faktor, salah satunya adalah peran perawat di rumah sakit tersebut yang turut membantu pelaksanaan TAK Sosialisasi yang senantiasa dikembangkan di dalam kegiatan sehari-hari melalui proses keperawatan.

Ada juga jurnal (Priyo Purnomo As'hab, 2017) tentang Penerapan Terapi Aktivitas Kelompok Sosialisasi (TAKS) Sesi-1 (Kemampuan Memperkenalkan Diri) Pada Pasien Isolasi Sosial di ruang abimanyu, maespati dan pringgondani rumah sakit jiwa daerah Surakarta. Penerapan terapi aktivitas kelompok sosialisasi (TAKS) sesi1efektif terhadap perubahan perilaku Pasien isolasi sosial. Hasil penelitian dari (Nur et al., 2016) tentang pengaruh aktivitas kelompok sosialisasi terhadap kemampuan bersosialisasi pada Pasien isolasi sosial menarik diri di rumah sakit Khusus Daerah Provinsi Sulawesi Selatan terdapat pengaruh terapi aktivitas kelompok sosialisasi terhadap kemampuan pasien berinteraksi sosialdan Pasien yang sudah dilakukan terapi aktifitas kelompok (Post) sebagian besar masih telah mampu bersosialisasi sebanyak 14 responden 
(93,3\%) sedangkan Pasien yang kurang mampu bersosialisasi sebanyak 1 responden $(6,7 \%)$.

Rumusan masalah dalam karya ilmiah akhir ners ini adalah "Adakah Pengaruh Pemberian Terapi Aktivitas Kelompok Sosialisasi sesi 1-3 Terhadap Kemampuan Interaksi Pada Pasien Isolasi Sosial Di Ruang RIPD RSJD Dr. Amino Gondohutomo Provinsi Jawa Tengah.

Penerapan ini bertujuan 1) Mengetahui karakteristik pasien isolasi sosial di Ruang RIPD RSJD Amino Gondohutomo Provinsi Jawa Tengah. 2) Mengetahui kemampuan pasien sebelum mengikuti kegiatan TAKS sesi 1-3 di Ruang RIPD RSJD Amino Gondohutomo Provinsi Jawa Tengah. 3) Mengetahui kemampuan pasien setelah mengikuti kegiatan TAKS sesi 1-3 di Ruang RIPD RSJD Amino Gondohutomo Provinsi Jawa Tengah. 4) Mengetahui peningkatan kemampuan pasien setelah mengikuti kegiatan TAKS sesi 1-3 di Ruang RIPD RSJD Amino Gondohutomo Provinsi Jawa Tengah.

\section{METODE}

Jenis penerapan ini adalah jenis kuantitatif dengan menggunakan rancangan one group pre and post test desain menggunakan study kasus dengan tujuan untuk mengetahui adanya pengaruh terapi kelompok asertif terhadap peningkatan kemampuan interaksi pada pasien isolasi sosial menarik diri. Pengolahan data menggunakan pengkajian dimulai dari pendahuluan hingga evaluasi. Populasi pada penerapan ini adalah pasien dengan diagnosa isolasi sosia: menarik diri di ruang RIPD RSJD Dr. Amino Gondohutomo Provinsi Jawa Tengah yang berjumlah 4 orang, pasien sudah mendapatkan terapi generalis SP 1 sampai SP 4. Sampel pada penerapan ini berjumlah 2 responden yang dipilih menggunakan tekhnik random sampling yaitu pemilihan responden secara acak. Penerapan TAKS sesi 1-3 dilakukan selama 3 hari, evaluasi penerapan dilakukan setiap per sesi dan post-test dilakukan dihari keempat penerapan. Peralatan yang dibutuhkan yaitu : handphone, lagu yang ceria, bola tenis, lembar kuesioner aspek penilaian dan jadwal kegiatan pasien.

\section{HASIL}

Kemampuan memperkenalkan diri pada pasien isolasi sosial di ruang RIPD RSJD Dr. Amino Gondohutomo Provinsi Jawa Tengah meliputi kemampuan verbal dan non verbal. Penilaian kemampuan verbal meliputi kemampuan menyebutkan nama lengkap, menyebutkan nama panggilan, menyebutkan asal, dan menyebutkan hobi. Pasien tidak mampu menyebutkan nama lengkap sebelum dilakukan TAKS. Pasien juga tidak mampu menyebutkan asal dan hobi yang dimilikinya. Pasien hanya mampu menyebutkan nama panggilan saja. Setelah dilakukan TAKS pasien mampu melakukan semua aspek verbal yang dinilai. Penilaian kemampuan non verbal meliputi kontak mata, duduk tegak, dan menggunakan bahasa tubuh yang sesuai. Pasien tidak mampu melakukan ketiga aspek yang dinilai sebelum dilakukan TAKS. Setelah dilakukan TAKS pasien mampu duduk tegak saat memperkenalkan diri. Grafik 1 menunjukkan kemampuan memperkenalkan diri pasien sebelum dan setelah dilakukan TAKS.

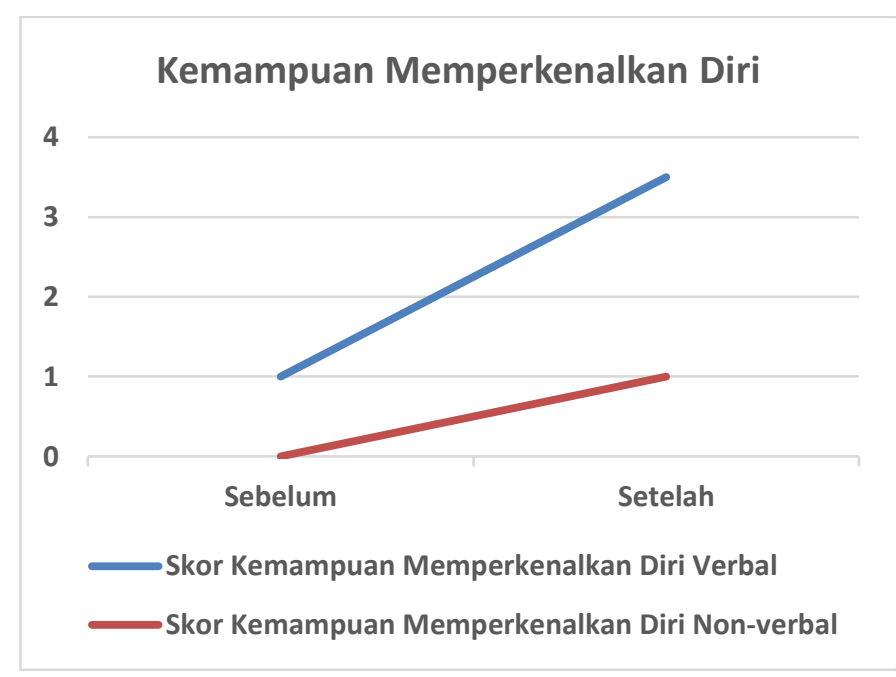

Grafik 1. Grafik Kemampuan Memperkenalkan Diri 
Kemampuan berkenalan pada pasien isolasi sosial di ruang RIPD RSJD Dr. Amino Gondohutomo Provinsi Jawa Tengah meliputi kemampuan verbal dan non verbal. Kemampuan verbal meliputi kemampuan pasien untuk menyebutkan nama lengkap, nama panggilan, asal, dan hobi. Kemampuan verbal lain meliputi kemampuan pasien untuk menanyakan nama lengkap, nama panggilan, asal, dan hobi. Kemampuan verbal yang mampu dilakukan pasien diantaranya pasien mampu menyebutkan nama panggilan dan menanyakan nama panggilan. Setelah dilakukan TAKS pasien mampu melakukan kemampuan verbal kecuali menanyakan nama lengkap. Penilaian kemampuan non verbal meliputi kontak mata, duduk tegak, menggunakan bahasa tubuh yang sesuai, dan mengikuti kegiatan dari awal sampai akhir. Pasien tidak mampu melakukan kontak mata pada saat berkenalan. Setelah dilakukan TAKS pasien mampu melakukan kontak mata dan mengikuti kegiatan dari awal sampai akhir. Grafik 2 menunjukkan kemampuan pasien saat berkenalan sebelum dan setelah dilakukan TAKS.

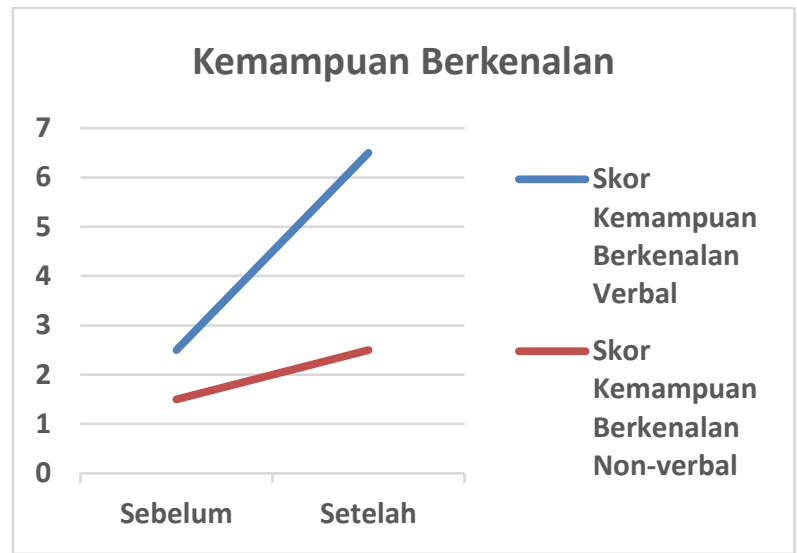

Grafik 2. Grafik Kemampuan Berkenalan

Kemampuan bercakap-cakap pada pasien isolasi sosial di ruang RIPD RSJD Dr. Amino Gondohutomo Provinsi Jawa Tengah meliputi kemampuan verbal bertanya dan menjawab. Kemampuan bertanya meliputi aspek mengajukan pertanyaan yang jelas, ringkas, relevan, dan spontan. Sedangkan kemampuan menjawab meliputi aspek kemampuan menjawab dengan jelas, ringkas, relevan, dan spontan. Sebelum dilakukan TAKS pasien tidak mampu menunjukkan kemampuan verbal saat bercakap-cakap. Setelah dilakukan TAKS pasien mampu mengajukan pertanyaan serta menjawab pertanyaan dengan jelas, ringkas, dan spontan namun belum relevan. Aspek penilaian kemampuan non verbal meliputi kontak mata, duduk tegak, menggunakan bahasa tubuh yang sesuai, dan mengikuti kegiatan dari awal sampai akhir. Sebelum dilakukan TAKS pasien hanya mampu melakukan kontak mata saat bercakap-cakap. Setelah dilakukan TAKS pasien mampu menunjukkan semua aspek kemampuan non verbal.

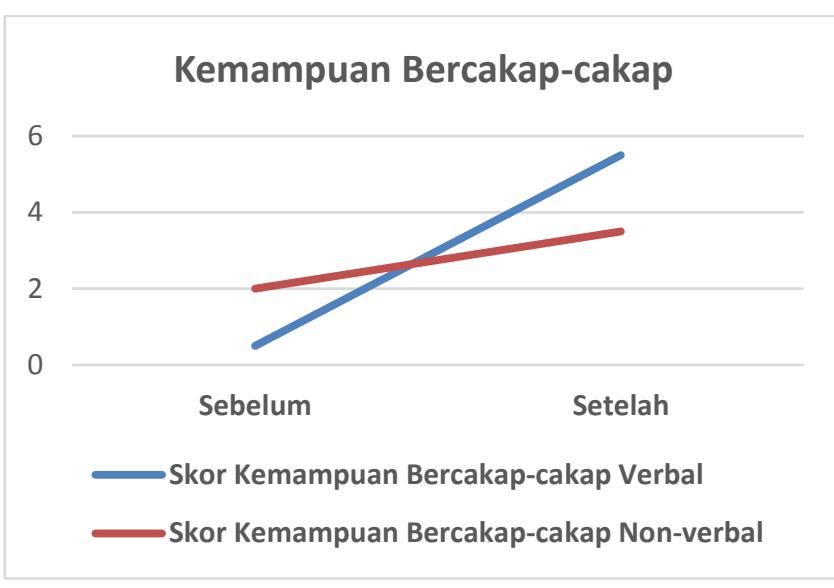

Grafik 3. Kemampuan Bercakap-cakap

\section{PEMBAHASAN}

Berdasarkan grafik 1 diketahui bahwa sebelum pasien mendapatkan terapi aktivitas kelompok sosialisasi sesi 1 (memperkenalkan diri) pasien dalam kategori belum mampu untuk memperkenalkan dirinya dimana pasien tidak mampu untuk menyebutkan nama lengkap, menyebutkan asal, dan menyebutkan hobi. Berdasarkan grafik 1 diketahui bahwa setelah pasien mengikuti terapi aktivitas kelompok sosialisasi sesi 1 (memperkenalkan diri) pasien mengalami peningkatan dalam kemampuan memperkenalkan diri dengan mampu untuk memperkenalkan diri secara verbal maupun non verbal sehingga dapat dikatakan pasien mampu untuk 
memperkenalkan diri, sedangkan untuk pasien yang lain juga mengalami peningkatan kemampuan memperkenalkan diri namun masih dalam kategori belum mampu memperkenalkan diri. Hal ini sejalan dengan teori yang mengatakan bahwa kegagalan pada pasien isolasi sosial: menarik diri disebabkan karena ketidakpercayaan individu, tidak percaya pada orang lain, tak ingin berkomunikasi degan orang lain, suka menyendiri dan tidak mementingkan kegiatan sehari-hari (Direja, 2011). Penerapan ini juga sejalan dengan penerapan yang dilakukan oleh SR Nasution (2015) pengaruh strategi pertemuan isolasi sosial terhadap kemampuan sosialisasi Pasien dengan jumlah responden sebesar 15 orang bahwa ketidakpercayaan individu salah satu menjadi penyebab kegagalan sosialisasi pada pasien dengan isolasi sosial. Penelitian lain juga menyebutkan bahwa adanya pengaruh pelaksanaan terapi aktivitas kelompok sosialisasi terhadap kemampuan sosialisasi pada Pasien dengan kerusakan interaksi sosial di Rumah Sakit Jiwa Dr. RM Soedjarwadi Klaten Jawa Tengah (Nur, Sri, 2016).

Berdasarkan grafik 2 diketahui bahwa sebelum pasien mendapatkan terapi aktivitas kelompok sosialisasi sesi 2 (berkenalan) Pasien hanya mampu melakukan 5 dari 12 kemampuan verbal maupun non verbal. Yang artinya pasien mendapatkan jumlah nilai $\leq 6$ kategori pasien belum mampu untuk berkenalan. Sedangkan untuk Pasien lain hanya mampu melakukan 3 dari 12 kemampuan verbal dan non verbal. Artinya pasien tersebut mendapatkan jumlah nilai $\leq 5$ dengan kategori pasien belum mampu untuk berkenalan. Berdasarkan table grafik 2 diketahui bahwa setelah pasien mengikuti terapi aktivitas kelompok sosialisasi sesi 2 (berkenalan) pasien mengalami peningkatan dalam kemampuan berkenalan dengan jumlah nilai 10 yang artinya kategori pasien mampu untuk berkenalan, sedangkan untuk pasien lainnya juga mengalami peningkatan kemampuan berkenalan dengan jumlah nilai 8 artinya pasien 2 dalam kategori mampu untuk berkenalan. Hal ini sejalan dengan teori yang mengatakan bahwa hubungan interpersonal adalah dimana ketika kita berkomunikasi kita bukan sekedar menyampaikan isi pesan, tetapi juga menentukan kadar hubungan interpersonalnya. Jadi ketika kita berkomunikasi kita tidak hanya menentukan content melainkan juga menentukan relationship. Dari segi psikologi komunikasi, kita dapat menyatakan bahwa makin baik hubungan interpersonal, makin terbuka orang untuk mengungkapkan dirinya; makin cermat persepsinya tentang orang lain dan persepsi dirinya; sehingga makin efektif komunikasi yang berlangsung diantara komunikan. Adanya hubungan terbuka pada anggota kelompok menimbulkan hubungan saling percaya antar anggota kelompok sehingga ada perasaan aman, senang pada diri Pasien setelah mengikuti kegiatan kelompok (Prabowo, 2014). Penerapan ini sejalan dengan penelitian Saswati \& Sutinah (2018) tentang pengaruh terapi aktivitas kelompok sosialisasi terhadap kemampuan sosialisasi Pasien isolasi sosial terdapat pengaruh terhadap kemampuan sosialisasi. Adapun penelitian yang lain menyebutkan bahwa pemberian terapi aktivitas kelompok sosialisasi terdapat pengaruh terhadap perubahan perilaku Pasien isolasi sosial (Surya, 2017).

Berdasarkan grafik 3 dapat diketahui bahwa sebelum pasien mendapatkan terapi aktivitas kelompok sosialisasi sesi 3 (bercakap-cakap) semua pasien masuk dalam kategori belum mampu untuk bercakap-cakap dengan anggota kelompok maupun orang lain. Berdasarkan grafif 3 diketahui bahwa setelah pasien mengikuti terapi aktivitas kelompok sosialisasi sesi 3 (bercakap-cakap) pasien mengalami peningkatan dalam kemampuan bercakapcakap dengan jumlah nilai 10 sedangkan pasien lain juga mengalami peningkatan dalam kemampuan bercakap-cakap dengan jumlah nilai 8 yang artinya bahwa semua pasien dalam kategori mampu untuk 
bercakap-cakap. Hal ini sejalan dengan penelitian dari Surtiningrum A (2016) terkait terapi suportif terhadap kemampuan bersosialisasi pada Pasien isolasi sosial adanya pengaruh terhadap peningkatan kemampuan bercakap-cakap pada pasien isolasi sosial menarik diri di RSJD Dr. Amino Gondohutomo Semarang.

Hasil penerapan TAKS sesi 1-3 selama 3 hari bisa disimpulkan bahwa responden dengan isolasi sosial: menarik diri setelah dilakukannya TAKS sesi 1-3 adanya peningkata kemampuan interaksi. Terjadinya gangguan dalam berhubungan dengan orang lain pada pasien dengan isolasi sosial dapat dipengaruhi oleh jenis kelamin. Dalam penerapan ini responden berjenis kelamin perempuan dan laki-laki dimana peningkatan lebih signifikan pada responden berjenis kelamin perempuan bahwa bagi perempuan adanya kepentingan dan hubungan pengasuhan dapat membuat mereka mengembangkan ketrampilan yang bersifat hirarki. Laki-laki disisi lain tidak mengalami kesulitan pada persaingan tetapi bermasalah dalam membuat hubungan dengan orang lain yang berarti bertentangan dengan kemandiriannya dan perempuan mempunyai kemampuan verbal dan bahasa lebih baik dibandingkan dengan laki-laki.

Penerapan ini sejalan dengan hasil penelitian Joko R (2015) di Rumah Sakit Jiwa Surakarta dimana terdapat pengaruh yang bermakna pada pemberian TAKS terhadap peningkatan kemampuan komunikasi pada pasien isolasi sosial. Penerapan ini juga sejalan dengan hasil penelitian dari (M.Sugeng, 2015) di Rumah Sakit Jiwa Provinsi Jawa Barat yang dimana hasilnya terdapat pengaruh TAKS sesi 1-3 terhadap peningkatan kemampuan interaksi pada pasien menarik diri.

Pemberian terapi kelompok suportif akan memotivasi klien untuk lebih berperan aktif berpikir dan berlatih terhadap kemampuan sosial yang di ajarkan. Hai ini menyebabkan pemberian terapi generalis dipadu dengan terapi kelompok suportif lebih efektif untuk menurunkan respon sosial (Hidayati, 2012).

\section{SIMPULAN}

Keluarga berperan dalam menentukan cara atau asuhan yang diperlukan di rumah. Tujuan diberikannya asuhan keperawatan kepada keluarga adalah agar keluarga pasien dapat merawat pasien di rumah dan menjadi system pendukung yang efektif untuk pasien. Keberhasilan perawat dirumah sakit dapat sia-sia jika tidak diteruskan di rumah yang kemudian mengakibatkan pasien harus dirawat kembali.

\section{REFERENSI}

Depkes RI. (2016). Profil Kesehatan Indonesia Tahun 2015.

Hidayati, Eni. (2012). Pengaruh Terapi Kelompok Suportif Terhadap Kemampuan Mengatasi Perilaku Kekerasan Pada Klien Skizofrenia Di Rumah Sakit Jiwa Dr. Amino Gondohutomo Kota Semarang. Ecological Economics, 1(1), 17.

https://doi.org/10.1017/CB0978110741532 4.004

Joko R. (2015). Pengaruh Pelaksanaan Terapi Aktivitas Sosialisasi Sesi 1 Dan 2 Terhadap Perubahan Kemampuan Interaksi Menarik Diri Klien Di Ruang Abimanyu, Ruang Maespati dan Ruang Pringgodani di RSJD Surakarta. Jurnal Ilmu Keperawatan Dan Kebidanan (JIKK), 3, 17.

Julianto A. B, Dwi H. R, P.-. (2015). pengaruh terapi aktifitas kelompok sosialisasi sesi 1-7 terhadap peningkatan kemampuan interaksi pada pasien isolasi sosial di RSJD DR.AMINO GONDOHUTOMO SEMARANG. Jurnal Ilmu Keperawatan Dan Kebidanan (JIKK), 1-10.

Keliat, A. (2014). Model Praktik Keperawatan Profesional Jiwa. EGC.

Keliat, B. . \& A. (2013). Terapi Aktivitas Kelompok. EGC.

M. Sugeng, R. (2015). Pengaruh Terapi Aktivitas Kelompok Sosialisasi Sesi 1-3 Terhadap Peningkatan Kemampuan Interaksi Pada Klien 
Menarik Diri Di Rumah Sakit Jiwa Provinsi Jawa Barat. Jurnal Endurance, 3, 1-12.

Makhfudi. (2010). Keperawatan Kesehatan Jiwa Komunitas: Teori dan Praktik Dalam Keperawatan. salemba medika.

Nur, M., Angraini, S., Nani Hasanuddin Makassar, S., \& Kemenkes Makassar, P. (2016). Pengaruh Terapi Aktivitas Kelompok Sosialisasi Terhadap Kemampuan Bersosialisasi Pada Klien Isolasi Sosial Menarik Diri Di Rumah Sakit Khusus Daerah Provinsi Sulawesi Selatan. Jurnal ISSN, 2(6), 1-15.

Nur, Sri, C. (2016). Pengaruh Pelaksanaan Terapi Aktivitas Kelompok Sosialisasi Terhadap Kemampuan Sosialisasi Pada Klien Dengan Kerusakan Interaksi Sosial di Rumah Sakit Jiwa Dr. RM Soedjarwadi Klaten Jawa Tengah. Jurnal Care No.3, 4, 1-9.

Prabowo, E. (2014). Konsep dan Aplikasi Asuhan Keperawatan Jiwa. Nuha Medika.

Pribadi, M. S., Muliani, R., \& Dirgahayu, I. (2016). Pengaruh Terapi Aktivitas Kelompok: Sosialisasi Sesi 1-3 Terhadap Kemampuan Komunikasi Verbal Pada Klien Menarik Diri. Bhakti Kencana Medika, No. 4, 2, 1-6.

Priyo Purnomo As'hab. (2017). Penerapan Terapi Aktivitas Kelompok Sosialisasi (TAKS) Sesi-1
(Kemampuan Memperkenalkan Diri) Pada Pasien Isolasi Sosial. Jurnal Keperawatan Soedirman, 5, 1-10. https://doi.org/10.1037/00223514.51.6.1173

Rachmaningtyas, A. (2013). Peningkatan tiap tahun jumlah sakit jiwa di Indonesia. Sindonews.

Saswati, N., \& Sutinah, S. (2018). Pengaruh Terapi Aktivitas Kelompok Sosialisasi Terhadap Kemampuan Sosialisasi Klien Isolasi Sosial. Jurnal Endurance, 3(2), 292. https://doi.org/10.22216/jen.v3i2.2492

SR Nasution, D. K. (2015). Pengaruh Strategi Pertemuan Isolasi Sosial Terhadap Kemampuan Sosialisasi Klien Di Rumah Sakit Jiwa Provinsi Sumatera Utara Medan. E-Journal Keperawatan (EKP), 4, 1-12.

Surtiningrum A, M. S. (2016). Pengaruh Terapi Suportif Terhadap Kemampuan Bersosialisasi Pada Klien Isolasi Sosial Di RSJD Dr. Amino Gondohutomo Semarang. E-Journal Keperawatan (EKP) No.3, 5, 1-15.

Surya, A. W. (2017). Pengaruh Pemberian Terapi Aktivitas Kelompok Sosialisasi Terhadap Perubahan Perilaku Klien Isolasi Sosial di RS Dr. Marzoeki Mahdi Bogor. Jurnal Keperawatan Jiwa,No:5, 3, 1-8. 